\title{
PERBEDAAN KEPUASAN KERJA DAN PERILAKU KEWARGANEGARAAN ORGANISASI BERDASARKAN KELOMPOK PROXIMAL WITHDRAWAL STATE
}

\author{
Alexander Abraham Daeng Kuma ${ }^{1}$, P. Tommy Y.S. Suyasa ${ }^{2}$, Raja Oloan Tumanggor ${ }^{3}$ \\ ${ }^{1}$ Program Studi Magister Psikologi Profesi, Universitas Tarumanagara Jakarta \\ Email: alexander.717171027@stu.untar.ac.id \\ ${ }^{2}$ Fakultas Psikologi, Universitas Tarumanagara Jakarta \\ Email: tommys@fpsi.untar.ac.id \\ ${ }^{3}$ Fakultas Psikologi, Universitas Tarumanagara Jakarta \\ Email: rajat@fpsi.untar.ac.id
}

Masuk : 21-04-2020, revisi: 28-04-2020, diterima untuk diterbitkan :30-04-2020

\begin{abstract}
Hospitality industry is one of those industry that need a maximum service for the consument, where as this kind of service can also be described as organizational citizenship behavior. One of the thing that can explain the act of organizational citizenship behavior is job satisfaction and the grouping in proximal withdrawal state. The aim of this study is to investigate the difference between job satisfaction and organizational citizenship behavior in hospitality worker based on proximal withdrawal state's grouping. Data collection was done using online and offline method, where three different questionnaire was used to measure job satisfaction, organizational citizenship behavior and decide the grouping of one's proximal withdrawal state. Based on this study, we found that there is a difference on job satisfaction and organizational citizenship behavior across the proximal withdrawal state's grouping. Those who belong to enthusiastic stayer and reluctant leaver group are showing higher job satisfaction and organizational citizenship behavior. Meanwhile, those who belong to reluctant stayer and enthusiastic leaver are showing lesser job satisfaction and organizational citizenship behavior. This research can give a clearer picture about how far those who work in hospitality industry can show their organizational citizenship behavior based on their proximal withdrawal state grouping.
\end{abstract}

Keywords: job satisfaction, organizational citizenship behavior, proximal withdrawal state, hospitality

\begin{abstract}
ABSTRAK
Industri hospitality merupakah salah satu industry yang sangat membutuhkan pelayanan yang maksimal untuk konsumen, dimana bentuk perilaku ini digambarkan sebagai perilaku kewarganegaraan organisasi. Salah satu hal yang dapat menjelaskan perilaku kewarganegaraan organisasi adalah kepuasan kerja seseorang dan kelompok proximal withdrawal state. Studi ini bertujuan untuk melihat perbedaan antara kepuasan kerja dan perilaku kewarganegaraan organisasi pada pekerja di industri hospitality berdasarkan kelompok proximal withdrawal state. Peneliti melakukan penyebaran data menggunakan kuesioner online dan offline, dimana terdapat tiga alat ukur yang digunakan untuk mengukur kepuasan kerja, perilaku kewarganegaraan organisasi dan menentukan kelompok proximal withdrawal state seseorang. Total terdapat 216 data yang dapat diolah pada studi ini. Dari studi yang dilakukan didapatkan bahwa ada perbedaan pada kepuasan kerja dan perilaku kewarganegaraan organisasi pada masing-masing kelompok proximal withdrawal state. Pekerja yang berada pada kelompok enthusiastic stayer dan reluctant leaver menunjukan kepuasan kerja dan perilaku kewarganegaraan organisasi yang paling tinggi, sementara pekerja pada kelompok reluctant stayer dan enthusiastic leaver menunjukan kepuasan kerja dan perilaku kewarganegaraan organisasi yang paling rendah. Hasil dari penelitian ini dapat memberikan gambaran yang lebih jelas mengenai bagaimana pekerja dapat menunjukan perilaku perilaku kewarganegaraan organisasi berdasarkan kelompok proximal withdrawal state mereka.
\end{abstract}

Kata Kunci: kepuasan kerja, perilaku kewarganegaraan organisasi, proximal withdrawal state, hospitality

\section{PENDAHULUAN}

\section{Latar Belakang}

Industri hospitality merupakan salah satu industri tertua yang ada di dunia. Istilah hospitality sendiri digunakan sebagai salah satu istilah payung untuk jenis usaha seperti restoran, jasa, usaha perjalanan, usaha perhotelan dan jenis usaha ritel. Hospitality sendiri didefinisikan sebagai sebuah 
perilaku yang bertujuan untuk menghibur pengunjung dengan niatan yang positif. Pada awalnya industri hospitality hanya mencakup jenis usaha yang berkaitan dengan hotel dan restoran, kemudian istilah hospitality digunakan lebih luas untuk mendefinisikan jenis usaha yang bergerak di bidang akomodasi, makanan dan minuman, jasa, transportasi darat atau laut dan juga bidang ritel (Ottenbacher, Harrington, \& Parsa, 2009).

Industri hospitality sendiri sangat bergantung pada bagaimana pekerja yang berada di bagian operasional dapat memberikan pelayanan yang memuaskan konsumen. Pekerja di industri hospitality sering kali dituntut untuk memenuhi tidak hanya apa yang menjadi kebutuhan yang ditunjukan oleh konsumen, namun hingga kebutuhan yang tidak ditunjukan secara eksplisit (Ocampo, Tan, \& Sia, 2018). Sering kali pekerja akan dituntut untuk bekerja jauh dari apa yang ada di tugas mereka untuk dapat memberikan servis yang paling memuaskan konsumen. Perilaku ini kemudian lebih dikenal dengan sebutan perilaku kewarganegaraan organisasi (Organ, 1988).

Istilah perilaku kewarganegaraan organisasi sendiri pertama kali didefinisikan oleh Barnard (dalam Organ, Podsakoff, \& MacKenzie, 2006) sebabagai extra role behavior sebagai bentuk perilaku individu yang mau untuk bekerja sama dan berkontribusi serta kooperatif dalam mencapai tujuan organisasi. Pada perkembangannya Organ (1988) mendefinisikan perilaku sebagai perilaku kewarganegaraan organisasi, yang didefinisikan sebagai sebuah perilaku yang dilakukan secara sukarela, tidak memengaruhi penilaian secara formal oleh perusahaan dan dapat meningkatkan efektifitas organisasi secara keseluruhan.

Pada awalnya perilaku kewarganegaraan organisasi hanya dikenal dengan dua dimensi, yaitu altruism dan compliance (Smith, Organ, \& Near, 1983). Namun pada perkembangannya Podsakoff, MacKenzie, Paine \& Bachrach (1990) mengembangkannya menjadi lima dimensi, yakni altruism, courtesy, civic virtue, sportsmanship dan conscientiousness. Hal ini merupakan pengembangan di mana awalnya perilaku kewarganegaraan organisasi hanya dianggap sebagai perilaku untuk membantu rekan kerja menjadi bentuk perilaku yang lebih kompleks. Contohnya saja menaati peraturan perusahaan, antuiasme dalam bekerja, hingga keinginan untuk membantu mengembangkan perusahaan (Podsakoff et al., 2000).

Perilaku kewarganegaraan organisasi sendiri dinilai penting oleh perusahaan karena memiliki beragam dampak positif, mulai dari meningkatnya work meaningfulness pada pekerja (Lam, Wan, \& Roussin, 2016), hingga peningkatan terhadap produktivitas pekerja secara langsung (Organ, Podsakoff , \& MacKenzie, 2006). Hal ini juga didukung oleh penelitian Nielsen, Hrivnak \& Shaw (2009), bahwa perilaku kewarganegaraan organisasi dapat memberikan dampak secara langsung pada performa pekerja secara individu ataupun organisasi.

Di industri hospitality sendiri, perilaku kewarganegaraan organisasi merupakan komponen yang sangat penting, terutama pada pekerja yang berhadapan langsung dengan konsumen (Chen, Hu, \& King, 2018). Hal ini dikarenakan kepuasan konsumen yang ada pada industri hospitality akan sangat bergantung pada bagaimana pekerja dapat memenuhi ekspektasi konsumen (Torres \& Kline, 2006), dan hal ini akan sangat menuntut pekerja untuk melakukan aktivitas yang bukan menjadi bagian tugasnya.

Perilaku kewarganegaraan organisasi memiliki anteseden seperti kepuasan kerja, kepribadian dan keadilan organisasi (Organ, Podsakoff, \& MacKenzie, 2006; LePine, Erez, \& Johsnon, 2002). Kepuasan kerja yang tinggi dapat menimbulkan performa kerja yang tinggi. Hal ini dilihat peneliti sebagai bentuk timbal balik dari apa yang dirasakan oleh pekerja terhadap perusahaan 
sehingga sebagai balasannya pekerja akan berusaha untuk bekerja semaksimal mungkin untuk berkontribusi bagi perusahaan.

Selain beberapa anteseden di atas, proximal withdrawal state yang dikemukakan oleh Hom, Mitchell, Lee, \& Griffeth (2012) juga dianggap dapat memprediksi perilaku perilaku kewarganegaraan organisasi. Dimulai dari anggapan dasar bahwa semua orang pada dasarnya akan meninggalkan perusahaan tempat mereka bekerja, model proximal withdrawal state berusaha untuk membagi pekerja menjadi empat kelompok, yang dikategorikan berdasarkan dua dimensi yakni keinginan untuk tinggal atau keluar dari perusahaan dan kontrol yang dimiliki untuk tetap tinggal atau keluar. Kombinasi dari kedua dimensi ini kemudian akan membagi pekerja menjadi empat tipe, yakni enthusiastic stayer, reluctant stayer, enthusiastic leaver dan reluctant leaver.

Hom, Mitchell, Lee, \& Griffeth (2012) mengungkapkan bawa pada dasarnya keempat kelompok tersebut akan memiliki tingkat kepuasan kerja yang berbeda. Di mana sudah dibuktikan melalui penelitian Li, Lee, Mitchell \& Griffeth (2016) mereka yang berada pada kelompok enthusiastic stayer dan reluctant leaver akan merasa puas dengan pekerjaan mereka. Sedangkan mereka yang berada pada kelompok reluctant stayer dan enthusiastic leaver akan merasa kurang puas dengan kondisi pekerjaan mereka. Berdasarkan hubungan yang ada pada kepuasan kerja dan perilaku kewarganegaraan organisasi, Hom, Mitchell, Lee, \& Griffeth (2012) menyatakan bahwa model yang ada pada proximal withdrawal state dapat memprediksi perilaku kewarganegaraan organisasi. Namun hingga saat ini belum banyak penelitian yang membuktikan secara langsung bagaimana kelompok yang ada pada proximal withdrawal state memprediksi perilaku kewarganegaraan organisasi pada pekerja.

Melalui alur berpikir di mana proximal withdrawal state dapat memprediksi kepuasan kerja pekerja dan kepuasan kerja dinilai sebagai salah satu anteseden dari perilaku kewarganegaraan organisasi, maka peneliti berusaha untuk membuktikan teori Hom, Mitchell, Lee, \& Griffeth (2012) di mana proximal withdrawal state dapat memprediksi kepuasan kerja dan perilaku kewarganegaraan organisasi pekerja.

Berdasarkan uraian yang ada di atas, peneliti tertarik untuk melihat bagaimana kategori seseorang pada kelompok proximal withdrawal state memengaruhi kepuasan kerja dan perilaku kewarganegaraan organisasi subjek.

Tabel 1. Hipotesis penelitian berdasarkan variable penelitian

\begin{tabular}{llll}
\hline $\begin{array}{c}\text { Kelompok Proximal } \\
\text { Withdrawal State }\end{array}$ & \multicolumn{1}{c}{ Kepuasan Kerja } & \multicolumn{1}{c}{$\begin{array}{c}\text { Perilaku Kewarganegaraan } \\
\text { Organisasi }\end{array}$} & $\begin{array}{c}\text { Hubungan Kepuasan } \\
\text { Kerja dan Perilaku } \\
\text { Kewarganegaraan } \\
\text { Organisasi }\end{array}$ \\
\hline Enthusiastic Stayer $(\mathrm{ES})$ & Paling tinggi & Paling tinggi & \\
\hline Reluctant Leaver $(\mathrm{RL})$ & $\begin{array}{l}\text { Lebih rendah dari ES, } \\
\text { lebih tinggi dari RS \& ES }\end{array}$ & $\begin{array}{l}\text { Lebih rendah dari ES, } \\
\text { lebih tinggi dari RS \& ES }\end{array}$ & Hubungan positif \\
\hline Reluctant Stayer $(\mathrm{RS})$ & Lebih rendah dari ES \& & $\begin{array}{l}\text { Lebih rendah dari ES \& } \\
\text { RL }\end{array}$ & RL \\
\hline Enthusiastic Leaver $(\mathrm{EL})$ & Lebih rendah dari ES \& & $\begin{array}{l}\text { Lebih rendah dari ES \& } \\
\text { RL }\end{array}$ & \\
\hline
\end{tabular}

\section{METODE PENELITIAN}

\section{Partisipan dan prosedur penelitian}

Responden penelitian ini merupakan pekerja yang sudah bekerja dan berada pada usia produktif (15-64 tahun) dan saat ini bekerja di industri hospitality. Industri hospitality sendiri digunakan 
untuk mendefinisikan usaha yang bergerak di bidang akomodasi, makanan dan minuman, jasa, transportasi darat atau laut dan juga bidang ritel (Ottenbacher, Harrington, \& Parsa, 2009). Partisipan diharuskan masih bekerja saat ini karena salah satu variabel yang akan diukur adalah kepuasan kerja dan ini hanya bisa diukur pada orang yang masih memiliki pekerjaan. Responden yang tergabung pada penelitian ini sendiri terdiri dari 305 partisipan, yang mengisi kuesioner secara online maupun offline. Pada kelanjutannya, tidak semua partisipan yang masuk diproses karena terdapat beberapa responden yang gugur pada saat divalidasi dengan alat ukur proximal withdrawal states. Selain itu peneliti juga menggugurkan beberapa partisipan yang mengisi kuesioner sebanyak dua kali maupun validitas partisipan yang rendah. Validitas rendah yang dimaksud adalah responden yang mendapatkan skor di bawah 3 pada alat ukur lanjutan proximal withdrawal state, yang berarti menggambarkan responden tidak benar-benar berada dalam situasi atau kelompok tersebut.

Pengumpulan data dilakukan dari tanggal 19 September 2018 hingga 15 November 2018. Partisipan menggunakan whatsapp sebagai media utama dalam menyebarkan dan melakukan pendekatan dengan responden untuk dapat mengisi kuesioner. Selain itu pemberian informasi mengenai cara mengisi juga dijelaskan melalui media online untuk memastikan tidak ada kesalahan pengisian pada kuesioner.

Terdapat 305 responden yang berhasil menyelesaikan kuesioner dan setelah melewati proses validasi dari kuesioner proximal withdrawal state maka ada 216 responden yang datanya dapat diolah. Kelompok responden terbagi menjadi 27 orang kelompok enthusiastic leaver (12.5\%), 45 orang kelompok reluctant stayer (20.8\%), 43 orang kelompok reluctant leaver (19.9\%) dan 101 orang kelompok enthusiastic stayer (46.8\%). Berdasarkan jenis kelamin, responden terbagi menjadi 116 orang perempuan $(53.7 \%)$ dan 100 orang laki-laki (46.3\%).

\section{Instrumen pengukuran}

Alat ukur untuk proximal withdrawal states sendiri diadaptasi dari milik Li, Lee, Mitchell, \& Griffeth (2016) yang berisikan pertanyaan pembuka untuk menentukan situasi saat ini dari empat pilihan yang ada dan dilanjutkan dengan empat sampai lima butir pada masing-masing situasi untuk menentukan apakah kandidat benarbenar berada pada situasi tersebut atau tidak. Contoh butir pada alat ukur untuk validasi kelompok enthusiastic leaver seperti "Saya ingin keluar dari perusahaan saya saat ini dan tidak ada yang bisa membuat saya tetap bekerja di perusahaan ini"; untuk alat ukur validasi kelompok reluctant stayer seperti "Saya ingin keluar dari perusahaan saya saat ini tetapi hal ini sulit untuk dilakukan"; untuk alat ukur validasi kelompok enthusiastic leaver seperti "Jika saya keluar dari perusahaan saya saat ini dalam waktu dekat maka hal ini akan sangat disebabkan oleh faktor luar yang tidak bisa saya kendalikan, tetapi saya ingin tetap bekerja di perusahaan ini"; dan alat ukur untuk validasi kelompok enthusiastic stayer seperti "Saya yakin perusahaan ingin saya menetap di perusahaan untuk beberapa waktu kedepan dan sayan ingin menetap di perusahaan"

Alat ukur untuk kepuasan kerja sendiri diadaptasi dari Brayfield \& Rothe (1951, dalam Curry, Wakefield, Price, \& Muller 1986). Contoh butir pada alat ukur ini adalah, "Saya merasa kurang puas atau kurang nyaman dalam menjalankan tugas atau pekerjaan saya". Alat ukur ini memiliki Alpha Cronbach's 0,86.

Alat ukur untuk perilaku kewarganegaraan organisasi sendiri diadaptasi dari Podsakoff et al. (1990) dengan lima dimensi yakni sportsmanship, courtesy, civic virtue, altruism dan conscientiousness. Beberapa contoh item dari alat ukur ini seperti, "Saya bersedia menerima tugas tambahan yang diakibatkan oleh absennya rekan kerja" yang menggambarkan dimensi 
altruism; "Saya mengikuti peraturan dan regulasi perusahaan meskipun tidak ada yang mengawasi" yang menggambarkan dimensi conscientiousness; "Saya selalu mengatakan kepada orang lain bahwa hasil kerja saya tidak terlepas dari kontribusi rekan saya" yang menggambarkan dimensi courtesy, "Saya sadar akan bagaimana perilaku saya dapat memengaruhi kinerja orang lain" yang menggambarkan dimensi civic virtue; "Saya berusaha untuk fokus pada hal positif pada sebuah permasalahan" yang menggambarkan dimensi sportsmanship. Alat ukur yang diadaptasi terdiri dari 24 butir dengan Alpha Cronbach's sebesar 0,935 Semua alat ukur tersebut menggunakan skala likert dengan rentang 1 sampai 5 dengan nilai 1 untuk menggambarkan kondisi tidak setuju dan nilai 5 untuk menggambarkan kondisi setuju.

\section{HASIL DAN PEMBAHASAN}

Sebelum pengujian hipotesis dilakukan, peneliti melakukan uji normalitas pada data masingmasing variabel dan didapatkan bahwa sebaran data tidak normal. Karena itu untuk uji perbedaan digunakan uji Kruskal-Walis dan didapatkan bahwa terdapat perbedaan pada kepuasan kerja dan perilaku kewarganegaraan organisasi berdasarkan kelompok proximal withdrawal state.

Pada variabel kepuasan kerja pengujian post-hoc dilakukan dengan metode LSD karena data yang diolah memiliki varians yang homogen. Hasil pengujian menunjukan bahwa terdapat perbedaan yang signifikan pada kepuasan kerja di masing-masing kelompok proximal withdrawal state.

Tabel 1. Uji LSD Post Hoc Berdasarkan

Kepuasan Kerja

\begin{tabular}{ccc}
\hline Kelompok PWS & Kelompok Pembanding & Signifikansi \\
\hline ES (4.09) & $>\operatorname{RL}(3.52)$ & Signifikan** \\
& $>\operatorname{RS}(3.15)$ & Signifikan** \\
& $>\operatorname{EL}(2.71)$ & Signifikan** \\
RL (3.52) & $>$ RS $(3.15)$ & Signifikan* \\
& $>\operatorname{EL}(2.71)$ & Signifikan** \\
EL (2.71) & $<$ RS (3.15) & Signifikan* \\
\hline
\end{tabular}

Catatan: ES = Enthusiastic Stayer $; \mathrm{RL}=$ Reluctant Leaver $; \mathrm{RS}=$ Reluctant Stayer $; \mathrm{EL}$

$=$ Enthusiastic Leaver

$* \mathrm{p}<0,05 * * \mathrm{p}<0,01 ; t s=$ tidak signifikan

Pada variabel perilaku kewarganegaraan organisasi pengujian post-hoc dilakukan dengan metode Games-Howell karena data yang diolah memiliki varians yang tidak homogen. Hasil pengujian menunjukan perbedaan yang signifikan pada masing-masing kelompok kecuali antara kelompok reluctant leaver dan enthusiastic stayer.

Tabel 2. Uji Games-Howel Post Hoc Berdasarkan

Perilaku Kewarganegaraan Organisasi

\begin{tabular}{ccc}
\hline Kelompok PWS & Kelompok Pembanding & Signifikansi \\
\hline ES (4.18) & $=$ RL (4.16) & $t s$ \\
& $>$ RS (3.56) & Signifikan ** \\
& $>$ EL (2.54) & Signifikan ** \\
RL (4.16) & $>$ RS (3.56) & Signifikan *
\end{tabular}




$\begin{array}{lll} & >\operatorname{EL}(2.54) & \text { Signifikan ** } \\ \text { EL }(2.54) & <\mathrm{RS}(3.56) & \text { Signifikan ** }\end{array}$

Catatan: ES = Enthusiastic Stayer $; \mathrm{RL}=$ Reluctant Leaver $; \mathrm{RS}=$ Reluctant Stayer $; \mathrm{EL}$ $=$ Enthusiastic Leaver

$* \mathrm{p}<0,05 * * \mathrm{p}<0,01 ;$ ts = tidak signifikan

Pengujian pada hubungan antara kepuasan kerja dan perilaku kewarganegaraan organisasi dilakukan dengan uji spearman dikarenakan sebaran data yang tidak normal. Berdasarkan hasil uji korelasi, didapatkan nilai signifikansi .537 ( $\mathrm{p}>0.01$ ) yang berarti ada hubunga antara kepuasan kerja dengan perilaku kewarganegaraan organisasi. Pengujian lebih lanjut dengan melakukan uji hubungan antara kepuasan kerja dan perilaku kewarganegaraan organisasi pada masing-masing kelompok proximal withdrawal state dan ditemukan hasil bahwa kedua variabel tersebut tidak memiliki hubungan hanya pada kelompok reluctant leaver.

Tabel 3. Koefisien Korelasi Kepuasan Kerja dan Perilaku Kewarganegaraan Organisasi Berdasarkan Kelompok Proximal Withdrawal State

\begin{tabular}{lc}
\hline \multicolumn{1}{c}{ Variabel Penelitian } & $\begin{array}{c}\text { Koefisien Korelasi Kepuasan Kerja \& Perilaku } \\
\text { Kewarganegaraan Organisasi }\end{array}$ \\
\hline Enthusiasitc Leaver & $.481^{*}$ \\
\hline Reluctant Stayer & $.438^{* *}$ \\
\hline Reluctant Leaver & .156 \\
\hline Enthusiastic Stayer & $.469^{* *}$ \\
\hline
\end{tabular}

Keterangan: *korelasi signifikan $\mathrm{p}>0,05$; **korelasi signifikan $\mathrm{p}>0,01$

Apabila melihat hasil pengujian dengan studi yang dilakukan oleh Li, Lee, Mitchell, \& Griffeth (2016), maka didapatkan hasil yang hampir serupa pada variabel kepuasan kerja, di mana kelompok enthusiastic stayer akan memiliki nilai tertinggi dan disusul dengan kelompok reluctant leaver, reluctant stayer dan enthusiastic leaver. Hanya saja pada saat membandingkan perilaku kewarganegaraan organisasi antar kelompok proximal withdrawal state, perbedaan yang signifikan tidak ditemukan antara kelompok enthusiastic stayer dan reluctant leaver. Hal ini dapat disebabkan karena tidak adanya hubungan antara kepuasan kerja dengan perilaku kewarganegaraan organisasi pada kelompok reluctant leaver, sehingga meskipun nilai kepuasan kerja kelompok enthusiastic stayer lebih tinggi dibandingkan reluctant leaver, kedua kelompok ini bisa menunjukan perilaku kewarganegaraan organisasi yang sama tingginya.

Hal ini dapat menunjukan bahwa perilaku kewarganegaraan organisasi pada pekerja yang berada di kelompok reluctant leaver bisa jadi dipengaruhi oleh faktor lain (Li, Lee, Mitchell, \& Griffeth, 2016). Selain itu pada penelitian yang dilakukan oleh Hom, Mitchell, Lee \& Griffeth (2012), sebenarnya mereka yang berada pada kelompok reluctant leaver bisa jadi menunjukan kepuasan yang sama dengan kelompok enthusiastic stayer, sehingga perilaku kewarganegaraan organisasi yang ditunjukan pun berada pada tingkatan yang sama. Hanya saja seiring berjalannya waktu maka dapat terjadi penurunan baik pada kepuasan kerja maupun perilaku kewarganegaraan organisasi yang dimiliki oleh kelompok reluctant leaver karena mereka yang berada pada kelompok ini pada dasarnya harus keluar dari tempat kerja mereka di luar keinginan mereka. 


\section{KESIMPULAN DAN SARAN}

Terdapat beberapa hal yang bisa disimpulkan dari hasil penelitian ini. Yang pertama, bahwa pada dasarnya terdapat perbedaan kepuasan kerja pada masing-masing kelompok Proximal Withdrawal State, dimana kelompok enthusiastic leaver akan memiliki kepuasan kerja tertinggi, diikuti kelompok reluctant leaver, reluctant stayer dan enthusiastic leaver. Kedua, perbedaan yang signifikan pada variabel perilaku kewarganegaraan organisasi juga terdapat pada hampir semua kelompok proximal withdrawal state. Kelompok enthusiastic stayer dan reluctant leaver memiliki nilai tertinggi, disusul dengan kelompok reluctant stayer dan enthusiastic leaver.

Ketiga, hubungan antara kepuasan kerja dan perilaku kewarganegaraan organisasi secara signifikan ditemukan pada hampir semua kelompok proximal withdrawal state, kecuali kelompok reluctant leaver. Hal ini dapat menjelaskan mengapa meskipun perbedaan antara kelompok terdapat pada variabel kepuasan kerja namun pada variabel perilaku kewarganegaraan organisasi tidak ditemukan perbedaan yang signifikan antara kelompok enthusiastic stayer dan reluctant leaver. Hal ini dapat membuka peluang lebih lanjut untuk melihat variabel lain yang dapat memengaruhi perilaku kewarganegaraan organisasi pada kelompok proximal withdrawal state tersebut.

Dalam melihat kelompok proximal withdrawal state, seharusnya peneliti bisa menggunakan pengelompokan yang lebih detail pada proximal withdrawal state seperti yang dikemukakan Hom, Mitchell, Lee, \& Griffeth (2012), di mana kelompok pekerja bisa terbagi menjadi 12 kelompok yang lebih spesifik berdasarkan keinginan pekerja untuk keluar dari perusahaan dan kontrol yang mereka miliki untuk tinggal atau keluar dari perusahaan. Hom, Mitchell, Lee, \& Griffeth (2012) mencontohkan tidak semua orang yang berada pada kondisi enthusiastic stayer merupakan pekerja yang produktif dan memiliki tingkat kepuasan kerja yang tinggi. Bisa jadi mereka adalah tipe pekerja yang berada pada sub-kategori slackers, di mana mereka puas dengan pekerjaan mereka, ingin dan bisa menetap di perusahaan mereka bekerja sekarang tanpa khawatir untuk mengalami pemutusan hubungan kerja tetapi dinilai tidak produktif. Penelitian lebih lanjut mengenai kelompok yang lebih kecil pada teori proximal withdrawal state dapat lebih digali untuk memberikan gambaran yang lebih komprehensif mengenai situasi tiap kelompok dan perilaku yang bisa dimunculkan.

Penelitian lanjutan juga dapat dilakukan dengan menggunakan sampel dari kelompok pekerja yang berbeda. Selain itu dapat dilihat juga bagaimana aspek demografis seperti usia, jenis kelamin, tingkat pendidikan maupun jabatan seseorang dalam menggambarkan kepuasan kerja maupun perilaku kewarganegaraan organisasi pada tiap kelompok proximal withdrawal state.

\section{Ucapan Terima Kasih}

Terima kasih sebesar-besarnya untuk pihak yang sudah mendukung penelitian ini, mulai dari subjek penelitian, dosen yang sudah memberikan masukan terkait dengan variable penelitian dan juga pihak-pihak lain yang tidak dapat disebutkan satu-persatu.

\section{REFERENSI}

Chen, C. T., Hu, H. S., \& King, B. (2018). Shaping the organizational citizenship behavior or workplace deviance: Key determining factors in the hospitality workforce. Journal of Hospitality and Tourism Management, 35, 1-8. https://doi.org/10.1016/j.jhtm.2018.01.003

Curry, J. P., Wakefield, D. S., Price, J. L., \& Mueller, C. W. (1986). On the causal ordering of job satisfaction and organizational commitment. Academy of Management Journal, 29(4), 847858. doi: $10.2307 / 255951$ 
Hom, P. W., Mitchell, T. R., Lee, T. W., \& Griffeth, R. W. (2012). Reviewing employee turnover: Focusing on proximal withdrawal states and an expanded criterion. Psychological Bulletin, 138(5), 831- 858. https://doi.org/10.1037/a0027983

Lam, C. F., Wan, W. H., \& Roussin, C. J. (2016). Going the extra mile and feeling energized: An enrichment perspective of organizational citizenship behavior. Journal of Applied Psychology, 101(3), 379-391. doi: 10.1037/ap10000071

LePine, J.A., Erez, A., \& Johnson, D.E. (2002). The nature and dimensionality of organizational citizenship behavior, a critical review and meta-analysis. Journal of Applied Psychology, 87(1), 52-65. https://doi.org/10.1037/0021-9010.87.1.52

Li, J. J., Lee, T. W., Mitchell, T. R., Hom, P. W., \& Griffeth, R. W. (2016). The effects of proximal withdrawal states on job attitudes, job searching, intent to leave, and employee turnover. Journal of Applied Psychology. 101(10), 1436-1456. https://doi.org/10.1037/apl0000147

Nielsen, T. M., Hrivnak, G. A., \& Shaw, M. (2009). Organizational citizenship behavior and performance: A meta-analysis of group-level research. Small Group Research, 40(5), 555577. https://doi.org/10.1177/1046496409339630

Ocampo, L.A., Tan, T.A.G., \& Sia, L.A. (2018) Using fuzzy DEMATEL in modeling in the causal relationship of the antecedents of organizational citizenship behavior (OCB) in the hospitality industry: A case study in Phillipines. Journal of Hospitality and Tourism Management, 34, 11-29. doi: 10.1016/j.jhtm.2017.11.002

Organ, D. W. (1988). Organizational citizenship behavior: the good soldier syndrome. Lexington Books.

Organ, D. W., Podsakoff, P. M., \& MacKenzie, S. B. (2006). Organizational citizenship behavior: its nature, antecedent \& consequences. New York: Sage Publication.

Ottenbacher, M., Harrington, R., Parsa, H.G. (2009). Defining the hospitality discipline: a discussion of pedagogical and research implications. Journal of Hospitality \& Tourism Research, 33(3), 263-283. https://doi.org/10.1177/1096348009338675

Podsakoff, P. M., MacKenzie, S. B., Paine, J. B., \& Bachrach, D. G. (2000). Organization citizenship behavior: A critical review of the theoretical and empirical literature and suggestions for future research. Journal of Management, 26(3), 513-563. https://doi.org/10.1177/014920630002600307

Price, J. L., \& Mueller, C. W. (1981). A causal model of turnover for nurses. Academy of Management Journal, 24(3), 543-565. https://doi.org/10.2307/255574

Smith, C. A., Organ, D. W., \& Near, J. P. (1983). Organizational citizenship behavior: Its nature and antecedent. Journal of Applied Psychology, 68(4), 653-663. https://doi.org/10.1037/0021-9010.68.4.653

Torres, E. N., \& Kline, S. (2006). From satisfaction to delight: A model for the hotel industry. International Journal of Contemporary Hospitality Management, 18(4), 290-301. doi: $10.1108 / 09596110610665302$ 